\title{
Magnetic Resonance Imaging Contrast Agents - Issues of Concern, Safety, and Efficacy
}

\section{Alain L Fymat*}

Institute Professor, International Institute of Medicine and Science, California, USA

*Corresponding Author: Alain L Fymat, Institute Professor, International Institute of Medicine and Science, California, USA.
Received: March 20, 2021

Published: May 11, 2021

(C) All rights are reserved by Alain L Fymat.

\section{Abstract}

This article addresses important issues regarding the use of certain MRI contrast agents (linear and macrocylic gadolinium-based, non-gadolinium-based, iron-based, others). Specific attention is devoted to their corresponding safety and efficacy, and to their use or repeated use in patients with certain medical conditions.

Keywords: Imaging Agents; Linear Gadolinium-based; Macrocyclic Gadolinium-based; Non-gadolinium Based; Iron-based; Safety; Efficacy

\section{Abbreviations}

BBB: Blood-brain Barrier; CA: Contrast Agents; DTPA (or Pentetic Acid): Diethylenetriaminepentaacetic acid; EMA: European Medicines Agency; FDA: (U.S.) Food and Drug Administration; GBCA: Gadolinium-based Contrast Agents; Gd: Gadolinium; GDD: Gd Deposition Disease; IBMCA: Iron-based MRI Contrast Agents; LD: Lethal Dose; MEMRI: Manganese-enhanced MRI; MRI: Magnetic Resonance Imaging; MRA: Magnetic Resonance Angiography; NFD: Nephrogenic Fibrosing Dermopathy; NGBCA: Non-Gadolinium-based Contrast Agents; NSF: Nephrogenic Systemic Fibrosis; PMCA: Paramagnetic Contrast Agents; SIOP: Superparamagnetic Iron Oxide Particles; SIPP: Superparamagnetic Iron Platinum Particles; WHO: World Health Organization

Gadolinium-based contrast agents

Gadolinium-based contrast agents (GBCA) come in two flavors: linear and macrocyclic. For clarity, let me first define what is a stability constant and the macrocyclic effect:
- The stability constant (or formation constant, or binding constant) is an equilibrium constant in the formation of a complex solution and a measure of the solution's cohesion. It also informs on the solutes' concentrations. It is found in many applications including chelation therapy, poisoning treatment, and plutonium poisoning by DTPA (pentetic acid or diethylenetriaminepentaacetic acid) of interest in MRI's GBCA. On the other hand, the macrocyclic effect is a phenomenon that takes place when the stability of the complex solution is much greater than expected, involving both an entropy (a measure of randomness) and an enthalpy (a thermodynamic state function). factor.

Now, macrocyclic vs linear is an important dichotomy between macrocyclic ligands and open-chain (chelating) ligands in that they have selectivity for metal ions (a ligand is a substance that forms a complex with a biomolecule to serve a biological purpose).

As shown in table 1, there are eight extra-cellular fluid contrast agents; six for blood pool agents, one for hepatobiliary (liver) agents, and nine agents approved for human use. 


\begin{tabular}{|c|c|}
\hline $\begin{array}{l}\text { Extra-cellular } \\
\text { fluid }\end{array}$ & $\begin{array}{c}\text { Gadoderate (Dotarem, clariscan) } \\
\text { Gadodiamide (Omniscan) } \\
\text { Gadobenate (MultiHance) } \\
\text { Gadopentetate (Magnevist) } \\
\text { Gadoteridol (ProHance) } \\
\text { Gadoversetamide (OptiMARK) } \\
\text { Gadobutrol (Gadovist: EMA; Gadavist: FDA) } \\
\text { Gadopentetic acid dimeglumine (Magnetol) }\end{array}$ \\
\hline Bloo & $\begin{array}{c}\text { Albumin-binding Gd complexes } \\
\text { Gadofosveset (Ablavar, formerly Vasovist) } \\
\text { Gadocoletic acid } \\
\text { Polymeric Gd complexes } \\
\text { Gadomelitol } \\
\text { Gadomer }\end{array}$ \\
\hline $\begin{array}{l}\text { Hepatobilary } \\
\text { (liver) agents }\end{array}$ & $\begin{array}{c}\text { Gadoxetic acid (Primovist: EMA; Eovist: } \\
\text { FDA) [50\% excreted by liver; } 50 \% \text { excreted } \\
\text { by kidneys] }\end{array}$ \\
\hline $\begin{array}{l}\text { Agents approved } \\
\text { for human use } \\
\text { (EMA=European } \\
\text { Medicines Agency } \\
\text { FDA= (U.S.) } \\
\text { Food and Drug } \\
\text { Administration) }\end{array}$ & $\begin{array}{l}\text { Gadoterate (Dotarem; Clariscan in Europe): } \\
\text { EMA; FDA } \\
\text { Gadodiamide (Omniscan): EMA; FDA } \\
\text { Gadobenate (MultiHance): EMA; FDA } \\
\text { Gadpentetate (Magnevist: EMA; } \\
\text { Magnegita, Gado-MRT ratiopharm: FDA) } \\
\text { Gadoteridol (Prohance): EMA; FDA o } \\
\text { Gadofosveset (Ablavar, formerly Vasovist): } \\
\text { EMA, FDA } \\
\text { Gadoversetamide (OptiMARK): EMA; FDA } \\
\text { Gadoxetate (Eovist: EMA; Primovist: FDA) } \\
\text { Gadobutrol (Gadovist): EMA, FDA }\end{array}$ \\
\hline
\end{tabular}

Table 1: Various contrast agents and approval for human use.

\section{Non-gadolinium-based contrast agents}

There is quite a variety of non-gadolinium-based contrast agents (NGBCA) as charted in table 2, which classifies them according to their types, properties, and applications. In particular, the first four have the characteristic property of enhancing the T1relaxation time, the next five lower the T2-relaxation time, and the last one reduces the number of hydrogen ions in the body cavity.

\begin{tabular}{|c|c|c|}
\hline Type & $\begin{array}{c}\text { Components/ } \\
\text { properties }\end{array}$ & Applications \\
\hline Gd chelates & T1 enhancement & GI tract \\
\hline Mn chelates & & \\
\hline Fe salts & & \\
\hline $\begin{array}{c}\text { Natural products with } \\
\text { (blueberry, green tea) }\end{array}$ & T2 lowering & \\
\hline SPIO & Rencentration & \\
\hline Barium sulfate & $\begin{array}{c}\text { Reduces number } \\
\text { of H ions in body } \\
\text { cavity (appears } \\
\text { dark in images) }\end{array}$ & \\
\hline Iron salts & Pediatric GI \\
\hline Air & & \\
\hline Clay & & \\
\hline Perflubron & & \\
\hline
\end{tabular}

Table 2: Classification of non-gadolinium based contrast agents.

Paramagnetic contrast agents

Paramagnetic contrast agents (PMCA) make us of manganese and its ions. They enhance the T1-relaxation time and are used to detect liver and brain lesions, and also in animal studies (See table 3). The MEMRI (manganese-enhanced MRI) procedure that was in its early developmental stage is now more fully established.

\begin{tabular}{|c|c|c|}
\hline Type & $\begin{array}{c}\text { Components/ } \\
\text { properties }\end{array}$ & Applications \\
\hline $\begin{array}{c}\text { Manganese ions } \\
\text { Mn }^{2+}\end{array}$ & $\begin{array}{c}\text { Enhance T1 } \\
\text { Chelates dissociate } \\
\text { Chelates Mn- }\end{array}$ & $\begin{array}{c}\text { Detection of } \\
\text { liver lesions }\end{array}$ \\
DPDP & absorbed intra-cellularly \\
Early & and excreted in bile; and & frain imaging \\
developmental & DPDP that is eliminated & \\
stage & via kidney filtration & \\
(aka MEMRI:Mn- & Mn $^{2+}$ enters cells through \\
enhanced MRI) & calcium Ca ${ }^{2+}$ channels & \\
\hline
\end{tabular}

Table 3: Paramagnetic contrast agents properties and applications. 


\section{Iron-based MRI contrast agents}

Iron-based MRI contrast agents (IBMCA) are superparamagnetic. To clarify this property, paramagnetism and diamagnetism need first to be clarified as concepts. Paramagnetism is a weak form of parallel magnetism induced in nanoparticles under the influence of an external magnetic field. By contrast, in diamagnetism, the induced magnetic field is anti-parallel. Table 4 summarizes the needed contrast amounts to visualize certain organs and tissues and the importance of the state of the blood-brain barrier (BBB) in the case of brain lesions and tumors.

\begin{tabular}{|c|c|c|}
\hline $\begin{array}{l}\text { Organ or } \\
\text { tissue }\end{array}$ & $\begin{array}{c}\text { Needed contrast } \\
\text { amount }\end{array}$ & $\begin{array}{c}\text { Blood-brain barrier } \\
\text { effects }\end{array}$ \\
\hline Aorta & As low as $0.1 \mathrm{mmol} / \mathrm{kg}$ & Not applicable \\
\hline $\begin{array}{c}\text { Fine } \\
\text { vasculature }\end{array}$ & $\begin{array}{l}\text { Higher than } 0.1 \text { mmol. } \\
\text { kg }\end{array}$ & Not applicable \\
\hline $\begin{array}{l}\text { Lesions and } \\
\text { tumors: } \\
\text { In brain } \\
\text { In rest of the } \\
\text { body }\end{array}$ & & $\begin{array}{l}\text { Being hydrophilic, } \\
\text { Gd(III) chelates* do } \\
\text { not pass the intact } \\
\text { BBB, but are useful } \\
\text { where the BBB is } \\
\text { compromised and } \\
\text { GdIII leaks out } \\
\text { Initially Gd(III) } \\
\text { remains in } \\
\text { circulation but then } \\
\text { distributes into } \\
\text { interstitial space or } \\
\text { is eliminated by the } \\
\text { kidneys }\end{array}$ \\
\hline
\end{tabular}

Table 4: Tissue and organ visualization and effects of the bloodbrain barrier.

Now, there are two types of iron-based contrast agents:

- $\quad$ Superparamagnetic iron oxide particles (SIOP): Their sizes range from small to ultra-small. They have all been discontinued because of concerns about their safety.

- Superparamagnetic iron platinum particles (SIPP): These are still investigational.

Table 5 sets forth the various particulars of the SIOPs:

\begin{tabular}{|c|c|c|}
\hline Particle type & $\begin{array}{c}\text { Components/ } \\
\text { properties }\end{array}$ & Applications \\
\hline $\begin{array}{c}\text { SIOP } \\
\text { Feridex IV (aka Endorem } \\
\text { or ferumoxides } \\
\text { => Discontinued in } 2008 \\
\text { by AMAG Pharma } \\
\text { Resovist (aka Cliavist): } \\
\text { => Abandoned in 2009 } \\
\text { Sinerem (aka Combidex): } \\
\text { => Marketing authoriza- } \\
\text { tion application with- } \\
\text { drawn in 2007 } \\
\text { Lumirem (aka Gastro- } \\
\text { mark): } \\
\text { => Discontinued in 2012 } \\
\text { Clariscan (aka PEG-fero, } \\
\text { Feruglose, NC100150): A } \\
\text { macrocyclic extracellular } \\
\text { Gd containing gado- } \\
\text { teric acid and gadoterade } \\
\text { meglumine: } \\
\text { => Discontinued by } \\
\text { GE Healthcare in early } \\
\text { 2000s due to safety con- } \\
\text { cerns }\end{array}$ & $\begin{array}{c}\text { Suspended colloids } \\
\text { of iron oxide } \\
\text { nanoparticles } \\
\text { They Reduce T2 of } \\
\text { absorbing tissues }\end{array}$ & $\begin{array}{c}\text { Liver tumor } \\
\text { enhancement }\end{array}$ \\
\hline $\begin{array}{c}\text { SIPP } \\
\text { (investigational) }\end{array}$ & $\begin{array}{c}\text { Better T2 relaxivity } \\
\text { than SIOP } \\
\text { Encapsulated with } \\
\text { phospholipids to } \\
\text { create multifunc- } \\
\text { tional SIPP stealth } \\
\text { immunomicelles } \\
\text { Synthesized and } \\
\text { conjugated to } \\
\text { a monoclonal } \\
\text { antibody against } \\
\text { prostate-specific } \\
\text { membrane antigen }\end{array}$ & $\begin{array}{l}\text { Tumor spe- } \\
\text { cific: human } \\
\text { prostate } \\
\text { cancer cells }\end{array}$ \\
\hline
\end{tabular}

Table 5: Classification of superparamagnetic iron particles. 
Other contrast agents

Other contrast agents include protein-based, enzyme-activated, and calcium-ion dependent activation. These are shown in table 6. In particular, the protein-activated agents utilize the ability of some amino-acids to bind with Gd. The enzyme-activity agents affect the $\mathrm{T} 1$ and $\mathrm{T} 2$ relaxation times and, importantly, in contrast with other MRI modalities that give only anatomical information, they make molecular processes visible.

\begin{tabular}{|c|c|c|c|}
\hline Type & Variety & Components/properties & Applications \\
\hline Protein-based & & Abilities of some amino-acids to bind with Gd & \\
\hline Enzyme-activated & $\begin{array}{l}\text { B-galactosidase-activated } \\
\qquad \begin{array}{c}\text { (+ other possible } \\
\text { enzymes })\end{array}\end{array}$ & $\begin{array}{l}\text { T1, T2 affected by paramagnetic iron component when } \\
\text { enzyme-related reaction takes place } \\
\text { Compounds cause detectable change in image intensity } \\
\text { when in presence of active form of a certain enzyme } \\
\text { Distinguish from current contrast agents that give only ana- } \\
\text { tomical information => make molecular processes visible }\end{array}$ & $\begin{array}{l}\text { In vivo assays of } \\
\text { enzyme activity }\end{array}$ \\
\hline $\begin{array}{l}\mathrm{Ca}^{2+} \text { dependent } \\
\text { activation }\end{array}$ & & & \\
\hline
\end{tabular}

Table 6: Other contrast agents.

Safety and efficacy of linear vs. macrocyclic GBCAs

The safety and efficacy of linear vs. microcyclic gadoliniumbased contrast agents devolve from the following factors:

- Chelating carrier molecules, whether ionic or not, are either macrocyclic or linear. The former are the least likely to release very toxic Gd(III) compounds and are, consequently, the safest. About a dozen of them have been approved worldwide. While toxic, Gd(III) is generally regarded as safe when chelated with a toxicity comparable to the iodinated contrast agents used in X-ray and CT imaging.

- In persons with kidney disease, even several months after GBCA administration, Gd(III) can lead to the rare but severe complication of the systemic disease known as nephrogenic fibrosing dermopathy (NFD) or nephrogenic systemic fibrosis (NSF). Dialysis patients are more at risk than patients with chronic kidney disease.

- The World Health Organization (WHO) had issued the following restriction: “... high-risk gadolinium-containing contrast agents (Optimark, Omniscan, Magnevist, Magnegita, and Gado-MRT ratiopharm) are contraindicated in patients with severe kidney problems, in patients who are scheduled for or have recently received a liver transplant, and in newborn babies up to four weeks of age" (November 2009).
- Longer term adverse health effects of Gadolinium deposits in the body, the brain, and other tissues are unknown. Regulatory agencies have therefore issued several cautionary notices in this regard. Thus, the FDA issued a revision of its class warnings for all Gd-based contrast media, particularly in their retention characteristics, dosages, patient types (pregnant women, pediatric patients, and patients with inflammatory conditions) without necessarily avoiding or deferring the studies. Particular attention was given to: minimizing repeat or/and closely spaced studies, associated risks of stillbirths or neonatal deaths, and patient education.

- $\quad$ As with the FDA, the European Medicines Agency (EMA) has revised its conduct of the safety review of MRI contrast agents and implemented a change in its market authorization for all linear chelated Gd-based media.

- $\operatorname{Gd}(\mathrm{III})$ ions in water-soluble salts are toxic to mammals. As free ions, they are highly toxic. However, there is low or no toxicity for low dose ions. Chelated Gd(III) are far less toxic and are generally considered as safe enough for use in most cases. The process of chelation improves solubility and decreases toxicity (a factor of 100 or more), its strength determining its clinical toxicity. Anaphylactoid reactions are rare, occurring in about $0.03-0.1 \%$ of cases.

- Nephrogenic systemic fibrosis is a rare but serious disease that may occur months after a GBCA MRI in the case of renal 
impairment or severe kidney failure requiring dialysis. A similar but presenting different symptoms is Gadolinium deposition disease (GDD) that may also develop in normal or nearnormal renal function within hours to 2 months thereafter.

- $\quad$ GBCA-nanotubes are more effective than GBCAs (a factor of approximately 40), yielding a crisper contrast and permitting a more accurate diagnosis of abnormal growths and tumors.

- $\quad$ Current guidelines for the use of GBCA recommend for dialysis patients: considering gadolinium retention in selecting a GBCA, avoiding high-risk agents, performing the exam as near dialysis time as possible, administering an after-exam dialysis., and be particularly attentive to patients with inflammatory conditions or who may require multiple lifetime doses, pregnant women, and children.

\section{Summary and Conclusion}

GBCAs come in two flavors: Linear and macrocyclic. There is an important dichotomy between macrocyclic ligands and openchain (chelating) ligands in that they have selectivity for metal ions. There are eight extra-cellular fluid contrast agents; six for blood pool agents, one for hepatobiliary (liver) agents, and nine agents approved for human use. In MRI/MRA, Gadolinium nanotubes are 40 times more effective and more contrasting. They are usually safetr than iodinated contrast agents [1-17].

There are ten different varieties of non-Gadolinium based contrast agents. They have been developed for GI imaging. The tenth agent (Perflubron) is more specialized for pediatric GI. Some of these agents the T1-relaxation time, others the T2-relaxation time, and still another one reduces the number of hydrogen ions in the body cavity.

Paramagnetic contrast agents are based on manganese and its ions. They enhance the T1-relaxation time and are used to detect liver and brain lesions, and also in animal studies.

There are two types of iron-based MRI contrast agents. The first type made-up of superparamagnetic oxide particles was developed for liver tumor enhancement. It includes six different contrast agents that over the years have all been discontinued for safety reasons. The second type is made up of superparamagnetic platinum particles that are being developed specifically for prostate cancer cells. The safety and efficacy of linear vs microcyclic gadoliniumbased contrast agents devolve from the following factors. Unlikely to release Gd(III)-ions, cyclical ionic Gd(III) compounds are least likely to release the Gd(III) ion and, hence, are the safest with rare anaphylactoid reactions. are rare. In their chelated form, they are generally considered as safe. However, in persons with kidney disease, the rare but serious complication of nephrogenic fibrosing dermopathy (aka nephrogenic systemic fibrosis) may occur. Also, chronic kidney disease patients are less at risk of complications than dialysis patients. Cautionary notices have been issued by the FDA and the EMA regarding these agents.

\section{Bibliography}

1. Centers for Disease Control and Prevention (CDC). "Nephrogenic fibrosing dermopathy associated with exposure to gadolinium-containing contrast agents". MMWR. Morbidity and Mortality Weekly Report 56.7 (2007): 137-141.

2. "EMA recommendations on Gadolinium-containing contrast agents". ema.europa.eu. Retrieved 2018-07-12. "Information on Gadolinium-Containing Contrast Agents". Fda.gov.

3. "FDA warns that gadolinium-based contrast agents (GBCAs) are retained in the body; requires new class warnings" (PDF). United States Food and Drug Administration. 2017-12-19.

4. Fymat AL. "Magnetic Resonance Imaging with Nanocontrasting Materials", Invited Address presented at the BIT's 4th Annual Congress in Nanomedicine, Shuzou, China, June 2013 (2013).

5. Fymat. "Magnetic Resonance Imaging Modalities with Nanocontrasting Materials". Journal of Current Trends in Clinical and Medical Imaging 1.1 (2017): 1-4.

6. Geraldes CFGC and Laurent S. "Classification and basic properties of contrast agents for magnetic resonance imaging". Contrast Media and Molecular Imaging 4.1 (2009): 1-23.

7. Grobner T. "Gadolinium - a specific trigger for the development of nephrogenic fibrosing dermopathy and nephrogenic systemic fibrosis?". Nephrology Dialysis Transplantation 21.4 (2005): 1104-1108. 
8. Kanal E., et al. "ACR Guidance Document for Safe MR Practices: 2007". American Journal of Roentgenology 188.6 (2007): 14471474.

9. Koretsky Alan P and Silva Afonso C. "“Manganese-enhanced magnetic resonance imaging (MEMRI)". NMR in Biomedicine 17.8 (2004): 527-531.

10. Marckmann P., et al. "Nephrogenic Systemic Fibrosis: Suspected Causative Role of Gadodiamide Used for Contrast-Enhanced Magnetic Resonance Imaging". Journal of the American Society of Nephrology 17.9 (2006): 2359-2362.

11. Murphy KJ., et al. "Adverse reactions to gadolinium contrast media: A 1996 review of 36 cases". American Journal of Roentgenology 167.4 (1996): 847-849.

12. Qiao Jingjuan., et al. "Molecular imaging of EGFR/HER2 cancer biomarkers by protein MRI contrast agents". Journal of Biological Inorganic Chemistry 19.2 (2014): 259-270.

13. Rinck PA. “Chapter 13 - Contrast Agents”. Magnetic Resonance in Medicine (11th ed.). European Magnetic Resonance Forum. Retrieved 2020-07-31 (2017).

14. Sudarshana DM., et al. "Manganese-Enhanced MRI of the Brain in Healthy Volunteers". American Journal of Neuroradiology 40.8 (2019): 1309-1316.

15. Xue Shenghui., et al. "Design of a novel class of protein-based magnetic resonance imaging contrast agents for the molecular imaging of cancer biomarkers". Wiley Interdisciplinary Reviews: Nanomedicine and Nanobiotechnology 5.2 (2013): 163179.

16. Xue Shenghui., et al. "Design of ProCAs (Protein-Based Gd3+ MRI Contrast Agents) with High Dose Efficiency and Capability for Molecular Imaging of Cancer Biomarkers". Medicinal Research Reviews 34.5 (2014): 1070-1099.

17. Zhen Zipeng and Xie J . "Development of Manganese-Based Nanoparticles as Contrast Probes for Magnetic Resonance Imaging". Theranostics 2.1 (2012): 45-54.

\section{Assets from publication with us}

- Prompt Acknowledgement after receiving the article

- Thorough Double blinded peer review

- Rapid Publication

- Issue of Publication Certificate

- High visibility of your Published work

Website: www.actascientific.com/

Submit Article: www.actascientific.com/submission.php

Email us: editor@actascientific.com

Contact us: +919182824667 